\title{
Serum markers of liver fibrosis: Combining the BIPED classification and the neo-epitope approach in the development of new biomarkers
}

\author{
Sanne Skovgård Veidal ${ }^{\mathrm{a}, *}$, Anne-Christine Bay-Jensen ${ }^{\mathrm{a}}$, Gervais Tougas ${ }^{\mathrm{b}}$, Morten Asser Karsdal ${ }^{\mathrm{a}}$ and \\ Ben Vainer ${ }^{\mathrm{c}}$ \\ ${ }^{a}$ Department of Pharmacology, Nordic Bioscience, Herlev, Denmark \\ ${ }^{\mathrm{b}}$ Novartis Pharma AG Translational Medicine, Basel, Switzerland \\ ${ }^{\mathrm{c}}$ Department of Pathology, Rigshospitalet, University of Copenhagen, Denmark
}

\begin{abstract}
Background: Fibrosis is a central histological feature of chronic liver diseases and is characterized by the accumulation and reorganization of the extracellular matrix. The gold standard for assessment of fibrosis is histological evaluation of a percutaneous liver biopsy. Albeit a considerable effort have been invested in finding alternative non-invasive approaches, these have not been sufficiently succesfull to replace biopsy assessment.

Aim: To identify the extracellular matrix proteins of interest, that as protein degradation fragments produced during extracellular matrix metabolism neo-epitopes, may be targeted for novel biochemical marker development in fibrosis. We used the recently proposed BIPED system (Burden of disease, Investigative, Prognostic, Efficacy and Diagnostic) to characterise present serological markers.

Methods: Pubmed was search for keywords; Liver fibrosis, neo-epitopes, biomarkers, clinical trail, extra cellular matrix, protease, degradation, fragment.

Results and Conclusion: Implementation of BIPED categorization in the development and validation of fibrosis biomarkers to simplify and standardize the use of existing and future biomarkers seems advantageous. In addition, a systematic use of the neoepitope approach, i.e. the quantification of peptide epitopes generated from enzymatic cleavage of proteins during extracellular remodeling, may prove productive in the quest to find new markers of liver fibrosis.
\end{abstract}

Keywords: Fibrosis, biomarkers, neo-epitope, liver, diagnostics, BIPED, extracellular matrix, collagen, proteoglycan

\section{Introduction}

Chronic liver diseases are major global health problems with approximately 800,000 deaths annually worldwide [6,128]. Chronic liver injury, irrespective of the cause, is associated with progressive liver fibrosis,

* Corresponding author: Sanne Skovgård Veidal, Nordic Bioscience, Herlev Hovedgade 207, DK-2730 Herlev, Denmark. Tel.: +45 445477 32; Fax: +45 445488 88; E-mail: ssv@nordicbioscience. com. which is observed microscopically as excessive deposition and abnormal distribution of extracellular matrix (ECM) components. Progression of fibrosis eventually leads to end stage cirrhosis [29]. The sequence of events in liver fibrosis resembles that of wound healing and scar formation, including recruitment of inflammatory cells and proliferation and/or activation of matrixproducing cells, such as hepatic stellate cells (HSC), endothelial cells and hepatocytes. During chronic damage to the liver, the continuous insult leads to a constant imbalance between fibrogenesis and fibrolysis, which 

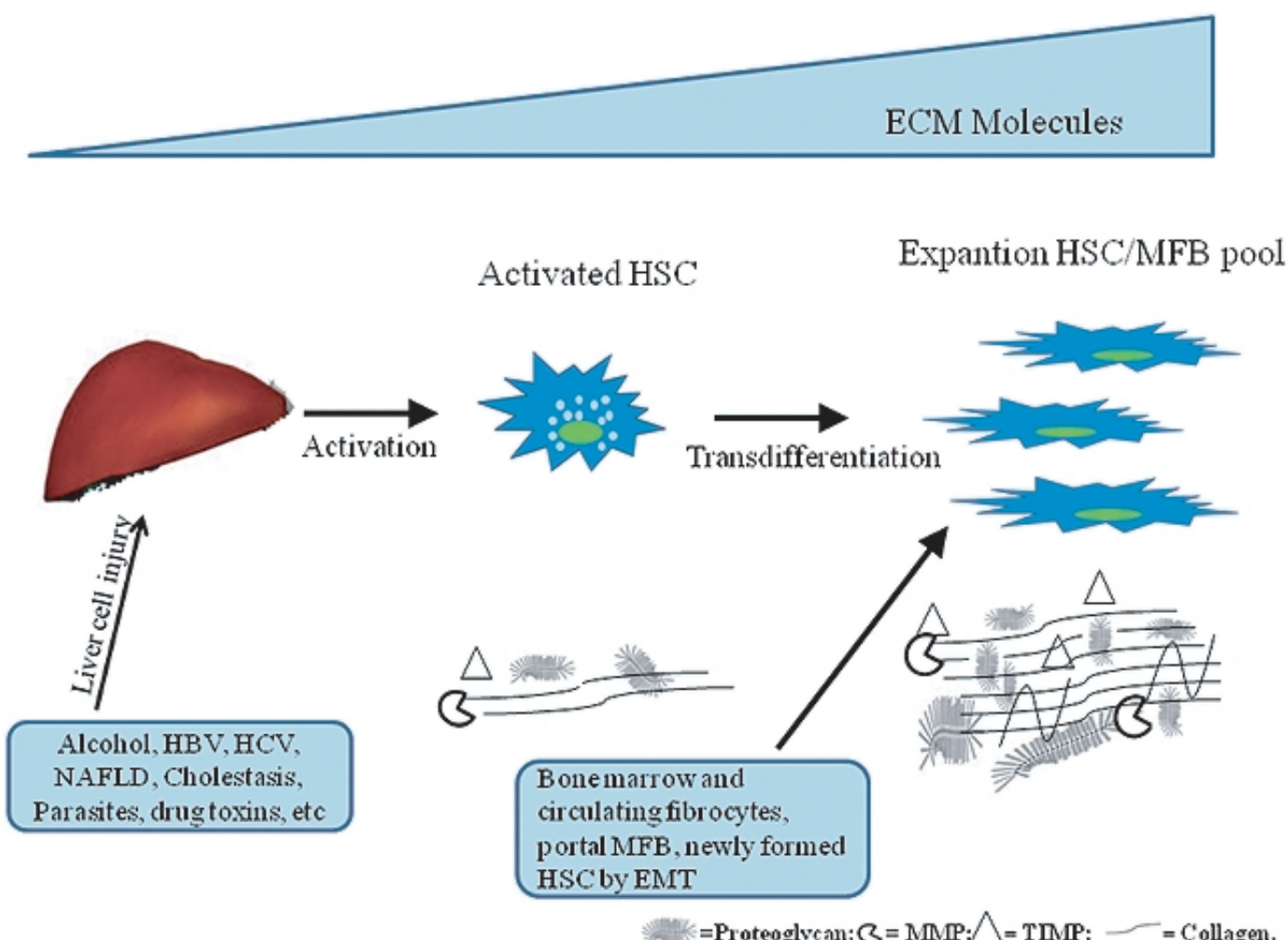

Fig. 1. Sequence of fibrogenesis as a result of liver cell injury. Liver cell injury causes activation of HSC and transdifferentiation into matrix-synthesizing MFB. $\triangle=$ TIMP; $\mathrm{B}=\mathrm{MMP}$; *w. =Proteoglycan; $-=$ Collagen. Abbreviations used: HBV/HCV, Hepatitis B/V virus; NAFLD, non-alcoholic fatty liver disease; ECM, extra cellular matrix; EMT, epithelial-to-mesenchymal transition; HSC, Hepatic stellate cell; MFB, Myofibroblast.

results in alteration of the tissue composition and accumulation of connective tissue [108].

Identification and characterization of the cell types and the different mediators involved in liver fibrogenesis have expanded significantly during recent years $[10$, 42,85]. HSC are identified as the driving force of liver fibrosis. When HSC are activated by inflammatory mediators [37] they differentiate into hepatic myofibroblast-like cells (hMFB) capable of expression and secretion of several connective tissue components (e.g. collagens, elastin, proteoglycans, and hyaluronan) (Fig. 1) [37,74]. HSC are believed to be the main source of ECM proteins accumulated in the liver during chronic liver disease. Besides HSC, resent research has clearly demonstrated that other cell types contribute to the hMFB-pool $[30,124,126]$. These cells can be from local sources such as portal myofibroblasts [61] as well as newly formed HSC that originate from a process called epithelial-to-mesenchymal transition (EMT) in which biliary epithelial cells or hepatocytes transform into fibroblasts [56]. In addition there is a contribution to the hMFB-pool from outside the liver from cells like bone marrow [27] and circulationg fibrocytes [102]. If the insult to the liver does not subsides, this excessive ECM deposition eventually results in liver cirrhosis and, ultimately, in liver failure.

Studies of humans and of animal models have suggested that some elements of fibrosis are reversible and, in specific circumstances, resolution with restoration to near normal organ architecture can be achieved [23, $24,45,53,98]$. Recent work on animal models continues to provide solid foundations to the essence of this concept [12]. The change of paradigm associated to these findings is set to provoke an increase in the efforts to develop new therapies that modulate or reverse the fibrogenic process.

Because of the invasive nature and the potential sideeffects of liver biopsy, serological disease markers are at present important tools for patient follow-up and treatment assessment. Candidate biomarkers for liver fibrosis have previously been classified into two categories [37]: Class I fibrosis markers are hypothesisdriven and based on molecular findings made in the study of fibrogenesis. Class II fibrosis markers are 
Table 1

Collagens of the hepatic extracellular matrix

\begin{tabular}{|c|c|c|c|c|}
\hline Group & Collagen type & Chains & Origin & Cellular source \\
\hline \multirow[t]{3}{*}{$\begin{array}{l}\text { Fibril forming } \\
\text { collagens }\end{array}$} & I $[34,36,78]$ & $\alpha_{1}(\mathrm{I}) \alpha_{2}(\mathrm{I})$ & Widely distributed & $\begin{array}{l}\text { HSC, MFB, sinusoidal, and portal } \\
\text { endothelial }\end{array}$ \\
\hline & III $[34,36,78]$ & $\alpha_{1}(\mathrm{III})$ & Widely distributed & $\begin{array}{l}\text { HSC, MFB, sinusoidal, and portal } \\
\text { endothelial }\end{array}$ \\
\hline & $\mathrm{V}[34,36,78]$ & $\alpha_{1}(\mathrm{~V}), \alpha_{2}(\mathrm{~V}), \alpha_{3}(\mathrm{~V})$ & Widely distributed & \\
\hline $\begin{array}{l}\text { Basement } \\
\text { membrane collagens }\end{array}$ & IV $[34,36,78]$ & $\alpha_{1}(\mathrm{IV}) \alpha_{2}(\mathrm{IV})$ & Basement membranes & $\begin{array}{l}\text { HSC, MFB, sinusoidal, and portal } \\
\text { endothelial, and bile duct epithelial } \\
\text { (levavasseur 1995) }\end{array}$ \\
\hline $\begin{array}{l}\text { Microfibrillar } \\
\text { collagen }\end{array}$ & VI [122] & $\alpha_{1}(\mathrm{VI}) \alpha_{2}(\mathrm{VI})$ & $\begin{array}{l}\text { Ubiquitously expressed in the } \\
\text { interstitial ECM }\end{array}$ & $\begin{array}{l}\text { HSC, MFB, sinusoidal, portal en- } \\
\text { dothelial, and bile duct epithelial }\end{array}$ \\
\hline $\begin{array}{l}\text { Hexagonal network- } \\
\text { forming collagens }\end{array}$ & VIII [62] & $\alpha_{1}(\mathrm{VIII}) \alpha_{2}(\mathrm{VIII})$ & Subendothelial space & Endothelial cells \\
\hline FACIT collagens & XIV [17] & & $\begin{array}{l}\text { Mainly found in } \\
\text { mesenchyme }\end{array}$ & Mesenchymal cells \\
\hline Multiplexins & $\begin{array}{l}\text { XIX [86] } \\
\text { XVIII [118] }\end{array}$ & & $\begin{array}{l}\text { Basement membranes, particu- } \\
\text { larly in the perisinusoidal space }\end{array}$ & $\begin{array}{l}\text { Hepatocytes }>\text { bile duct epithelial } \\
>\text { entothelial cells }>\text { HSC and MFB }\end{array}$ \\
\hline
\end{tabular}

mainly clinical laboratory tests that can relate biochemical changes in serum or plasma to liver disease status. Both approaches have been employed in the quest to find alternatives to liver biopsy examination, which is the current gold standard in liver disease diagnostic and monitoring. At present, the available scientific literature on liver fibrosis biomarkers contains a sizable number of experimental studies which differ in scope, design and methodology, making comparison of markers and approaches difficult. A classification system using simple robust parameters to categorize and evaluate the application the individual fibrosis biomarker, i.e. diagnostic, prognostic or burden of disease indications, would help understand the state of the art of novel and excisting markers and may allow better implementation of biochemical markers in study design and patient monitoring.

This review describes major ECM components that may be targeted in fibrosis biomarker research as potential type I biomarkers and introduces the BIPED classification (Burden of disease, Investigative, Prognostic, Efficacy of treatment and diagnostic). Finally, based on our experience from other pathologies of extensive ECM remodeling, we suggest to implement a novel approach for the identification and development of biochemical markers, namely by use of the neo-epitopes approach.

\section{Potential targets: The hepatic extracellular matrix}

Fibrogenesis during chronic liver diseases is a dynamic process involving complex cellular and molec- ular mechanisms [77]. Excessive fibrogenesis is the result of an imbalance between degradation and formation of ECM components. This will ultimately lead to increased liver size and density with progressively impaired liver function as the end-result. These ECM macromolecules are mainly fibrous proteins with structural and adhesive functions, such as collagens and proteoglycans.

\subsection{Collagens}

Collagens are responsible for the structural integrity of the ECM of most connective tissues, including that of the liver. The ECM content results from a fine balance between synthesis and degradation tightly controlled through regulation of gene expression and protein secretion, but also through endogenous protease inhibition and protein degradation by metalloproteinases (MMPs) and cysteine proteases [32,68,79]. Ten collagen types have been described in the liver (Table 1) [111]. Of those, the two major collagens are the fibril-forming types I and III. Fibril-forming collagens are predominantly synthesized by HSC as precursor molecules with large propeptide extensions at both the $\mathrm{N}$ - and C-terminal ends [31]. These propeptides are used as markers for liver fibrogenesis under various settings $[20,41]$. The mature propeptides are cleaved from procollagen by $\mathrm{N}$ - or $\mathrm{C}$-terminal proteinases, and the mature collagen is then integrated into the ECM [31, 34]. During fibrogenesis, type I and III collagen levels increase up to 8 times [36] with a significantly higher increase of type I collagen than of type III collagen, changing the I/III ratio from 1:1 in the healthy liver to 2:1 in the cirrhotic liver. As is demonstrated in Table 1, 
Table 2

Proteoglycans of the hepatic extracellular matrix

\begin{tabular}{|c|c|c|c|}
\hline Group & Proteoglycans & Other origin & Function \\
\hline $\begin{array}{l}\text { Large extracellular pro- } \\
\text { teoglycans (aggregating } \\
\text { and hyaluronan-binding) }\end{array}$ & Aggrecan $[60,67]$ & $\begin{array}{l}\text { Articular cartilage chondrocytes, } \\
\text { intervertebral disc, nasal cartilage }\end{array}$ & $\begin{array}{l}\text { Extracellular matrix stability (hyaluronan } \\
\text { binding) }\end{array}$ \\
\hline \multirow[t]{4}{*}{$\begin{array}{l}\text { Small leucine-rich proteo- } \\
\text { glycans (collagen-binding) }\end{array}$} & Decorin $[9,79]$ & Connective tissue, cartilage, bone & $\begin{array}{l}\text { Binds to and connect collagen molecules (matrix } \\
\text { stabilization and thickness) Organogenesis Binding } \\
\text { of TGF } \beta\end{array}$ \\
\hline & Biglycans $[26,83]$ & $\begin{array}{l}\text { Capillary endothelium, skin (ker- } \\
\text { atinocytes), epithelium of kidney }\end{array}$ & $\begin{array}{l}\text { Cell differentiation Binds and connect collagen } \\
\text { fibrils }\end{array}$ \\
\hline & Fibromodulin $[67,115]$ & Connective tissue, bone, cartilage & Regulate orientation of collagen fibers \\
\hline & Lumican $[9,67]$ & $\begin{array}{l}\text { Cornea, muscle, cartilage, kidney, } \\
\text { lung, intestine }\end{array}$ & Controls spacing and thickness of collagen fibers \\
\hline \multirow[t]{3}{*}{$\begin{array}{l}\text { Cell-associated } \\
\text { proteoglycans }\end{array}$} & Syndecans $[5,107,125]$ & $\begin{array}{l}\text { Widely distributed - often cell } \\
\text { membrane bound }\end{array}$ & $\begin{array}{l}\text { Binds collagens, fibronectin, thrombospondin, ten- } \\
\text { ascin and bFGF }\end{array}$ \\
\hline & & & $\begin{array}{l}\text { TGF } \beta \text { receptor and signaling Possible reservoir of } \\
\text { TGF } \beta\end{array}$ \\
\hline & Perlecan $[33,91,107]$ & All basement membranes & Selective barrier for macromolecules Cell-adhesion \\
\hline
\end{tabular}

the liver also contains other collagen types, all of which may be involved in the excessive fibrogenesis during fibrosis, leading to the end result of cirrhosis with a total of up to six times more collagen than in the normal liver [106].

\subsection{Proteoglycans}

Increasing attention is directed to the measurement and understanding of proteoglycans in the liver tissue, as these molecules in various forms and composition are associated with liver function. Proteoglycans are a diverse group of macromolecules that covalently bind a variable number of glycosaminoglycan (GAG) side chains to a core protein [46]. Table 2 lists the most studied proteoglycans found in the liver.

In the liver, proteoglycans are localized to the extracellular, pericellular spaces and on the cell surface, where they participate in cell-cell, cell-matrix and protein-protein interactions [55]. In the normal liver, the net amount of proteoglycans is low [78], whereas the level of several proteoglycans is increased during liver fibrosis [35]. Decorin is the most extensively studied proteoglycan in liver fibrosis [25,33,49,83] followed by biglycan, perlecan, aggrecan (in rodents), syndecan and lumican all showing elevated levels as a response to chronic liver injury. Animal studies have shown that chronic liver damage causes deposition of especially decorin, perlecan and biglycan in fibrotic septa [33,83], and syndecan-1 and -2 are increased on both mRNA and protein levels in the cirrhotic livers [55]. Indeed, an altered deposition and composition of proteoglycans in fibrotic tissue will lead to marked changes in the physiochemical properties of the tissue, inevitably changing the accessibility of regulatory factors and the cellular responses.

\section{The balance of tissue formation and degradation - proteases and their natural inhibitors}

The imbalance in liver fibrosis between synthesis and degradation of ECM results in conversion of the low-density subendothelial matrix into matrix rich in interstitial collagens (Fig. 2). The increase in collagen and proteoglycan can be the results of; increased protein production, impaired protein degradation, or diminished matrix degradation or a combination of those. The process of decreased protein degradation has recently received increased attention $[8,47]$. In the extracellular space, matrix degradation occurs predominantly as a consequence of the action of MMPs. MMPs are secreted from cells into the extracellular space as proenzymes, which are then activated by a number of specific, usually cell surface-associated, cleavage mechanisms. The active enzymes are in turn inhibited by a family of tissue inhibitors of metalloproteinases (TIMP) [3]. By this combination of mechanisms, extracellular matrix degradation is closely regulated, which prevents inadvertent tissue damage.

As a consequence, excessive matrix deposition may be the consequence of either increased formation, decreased degradation of connective tissue components or both.

\section{The gold standard for identification and follow-up of liver diseases}

Histopathologic examination of percutaneous liver biopsies is the gold standard for establishing diagnosis 
Normal

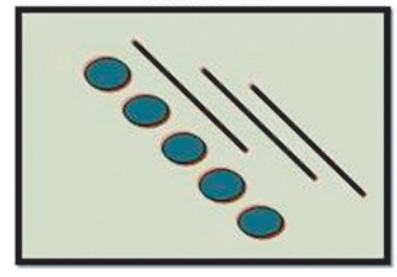

Diseased

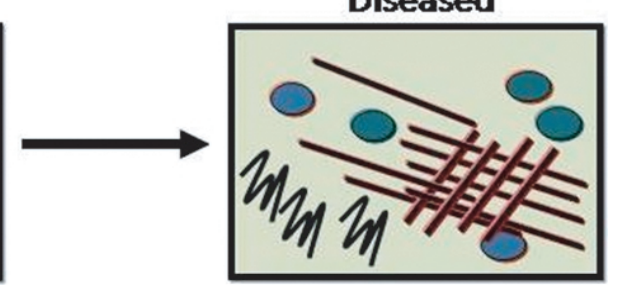

Fig. 2. Tissue loss, gain, and transformation during pathogenesis rely on extracellular matrix remodeling. The left picture shows ECM in healthy conditions where the cells $(\bigcirc)$ and ECM molecules $(\backslash)$ are highly organized. During fibrosis development the ECM changes composition and struction resulting in accumulation and changed structure (Right picture).

and staging of liver disease and it is the primary end point when evaluating the efficacy of new antifibrotic therapies. The analysis of consecutive liver specimens further allows evaluation of the progression of fibrosis (i.e. the stage of the disease [63]) and of the disease activity. However, the histopathological examination of liver biopsy presents a series of drawbacks. Besides being invasive with a mortality rate of $1 / 1,000-1 / 10,000$ and with a rate of severe complications of $1 / 200$, it is prone to sampling error since only $1 / 50,000$ of the liver mass is examined and is subjected to a reproducibility of only $35-45 \%$ [38]. Furthermore, histological evaluation is highly dependent on the experience of the pathologist, and even in the best of hands, the method may not unambiguously determine the stage of disease [38].

Different interpretation systems have been designed to minimize these uncertainties. The basic idea behind those systems is to standardize and integrate two or more histological features considered by medical consensus as having the highest predictive value (e.g. fibrosis, inflammatory activity and necrosis). Quantitative as well as qualitative scoring systems have been proposed. The semi-quantitative Knodell score [64] - and its modification, the Ishak score [52] - has been preferred for assessment of hepatitis in clinical trials. This evaluation system combines the assessment of periportal and/or bridging necrosis, intralobular degeneration and focal necrosis, portal inflammation, and fibrosis into an overall score.

\section{Which information can be obtained from measuring serological biomarkers of liver fibrosis?}

The use of liver biopsies provides static information of the disease, and some insights into the response to treatment when performed as serial biopsies. Serological biochemical markers have been used in other set- tings for prognostic use, especially for identification of "fast progressors" or those who possibly would benefit the most from treatment [109].

This implies that biopsies and serological markers may supply independent information, much as serological markers of bone resorption in combination with a bone mineral density testing by X-ray have provided osteoporotic patients with improved diagnostic and prognostic values $[48,59]$. The combination of a marker highly sensitive to changes together with a status assessment may be of use in monitoring patients with chronic liver disease.

\section{Classification of biomarkers}

Numerous attempts have been made to explore noninvasive markers that are capable of providing accurate information about fibrogenesis and the extent of fibrosis in the liver [117]. So far, however, the impact of biochemical markers of fibrosis in clinical practice has been very limited. Even when markers have proven useful in follow-up studies by providing complementary information to the histopathological analysis, no biomarker or combination of biomarkers has shown significant clinical or preclinical validity in replacing needle biopsy or minimizing animal experimentation $[37$, 38].

This failure of success may have different causes, of which one may be inconsequence in the classification of potential biomarkers. The most comprehensive classification of fibrosis biomarkers was published by Dr. Gressner and colleagues [38], who separated biomarkers into Class I and Class II biomarkers. Class I biomarkers are those intended to reflect ECM turnover and/or fibrogenic cell changes. Class II are indirect serum biomarkers based on algorithmic evaluations of commonly observed functional alterations of the liver that do not necessarily reflect ECM turnover and/or fibrogenic cell changes. Generally, Class I biomarkers 


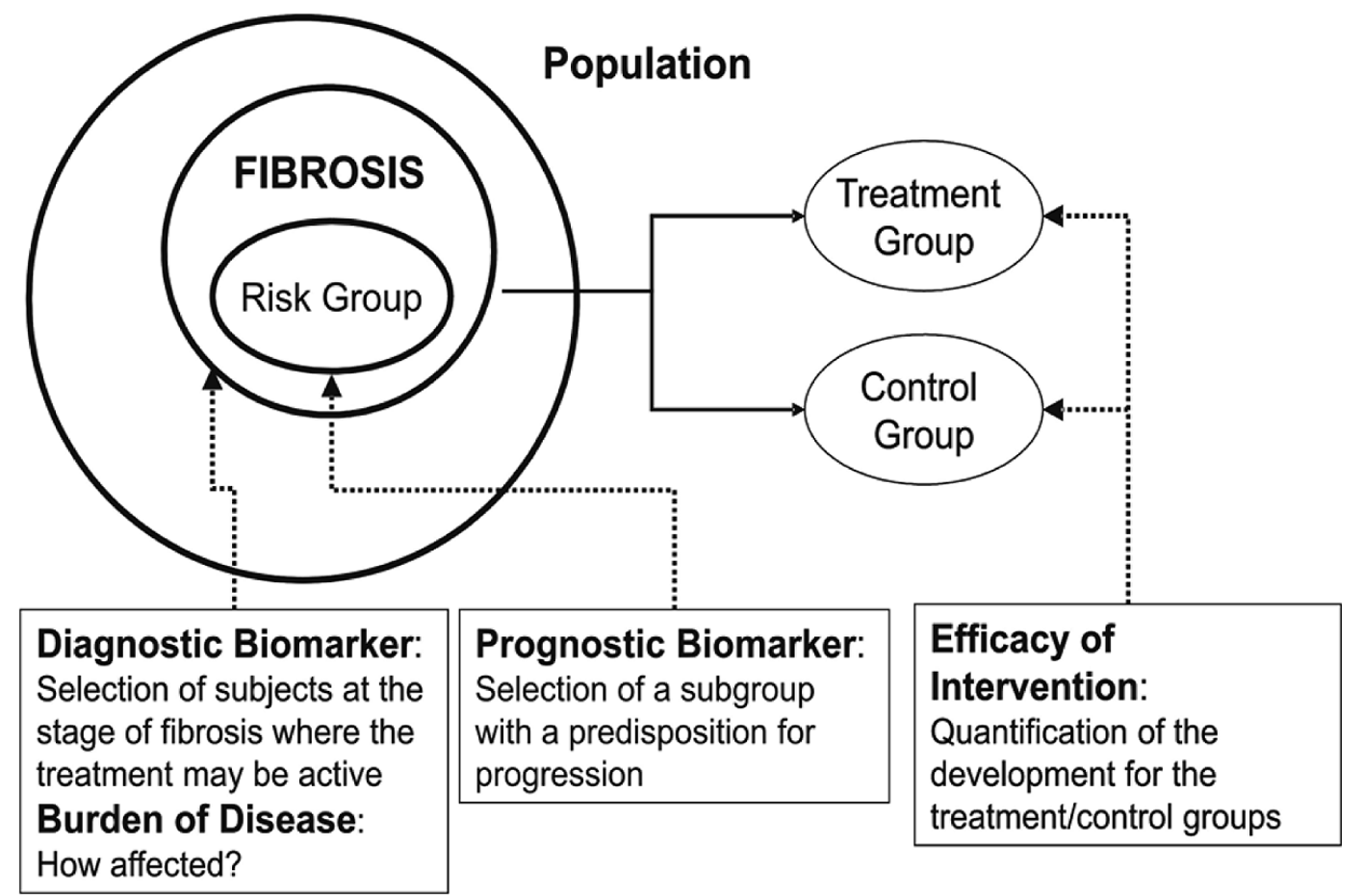

Fig. 3. Use of the BIPED classification to characterize markers of disease in a study population. The I-marker is the promising markers that need validation in the total population before application as B- or D-markers. B- and D-markers can define a study group within the total population (with or without disease) and within the study population (severity), respectively. The P-marker will give information about the progression of the disease in the study group or who are likely to develop the disease. The E-marker will give information about the efficacy of treatment received by the study group. S-marker defines the exact pathological stage of the disease.

derive from hypothesis driven research based on ECM biology and cellular mechanisms of pathology, whereas Class II biomarkers are identified from retrospective studies in which combinations of mostly classical clinical biochemistry parameters associated to liver function were tested for their predictive value. A disadvantage of this classification is that it does not provide information about the potential clinical use of the biomarkers nor does it go far enough in terms of recognizing, differentiating and understanding them. Class I biomarkers, in particular, originating from different lines of basic research and their changes, might be very difficult to interpret from a clinical or pathophysiological perspective. A functional classification, establishing concise standard definitions of biomarker types, would allow for a better understanding of the relationship between individual markers and between markers and clinical features. It would also help focusing research efforts and, ultimately, the chances of finding markers with in vivo applicability.

\section{The BIPED classification}

The BIPED classification categorizes biomarkers according to key parameters that are needed for assessment of clinical trials in research and development. Several classes have been defined: (i) Biomarkers that describe the progression of disease and that correlate with known clinical parameters (Burden of disease B); (ii) biomarkers that capture the effect of an intervention in both known and unknown biological mechanisms associated with clinical outcome and that can act as a surrogate marker, i.e. changes in these biomarkers can predict the clinical outcome (Efficacy - E); (iii) diagnostic biomarkers enabling identification of patients within the population and identification of subgroups within the diseased population (Diagnostic - D); (iv) biomarkers that identify subjects with high risk of progression (Prognostic - P); and (v) biomarkers not fully validated in a study population and therefore can be used solely for scientific investigations (InvestigatoryI). Figure 3 illustrates the relationship between the different biomarkers in the context of a study population. 
The purpose of a D-marker is to provide a clear discrimination between diseased and non-diseased subjects within the total population. A new diagnostic biomarker should be evaluated by comparison with the established gold standard with the appropriate spectrum of subjects. Initial verification would be obtained in a population from a cross-sectional dataset (optimally including patients with conditions that may clinically be confused with the target disease) or a case-control design with subjects with and without documented fibrosis. The clinical usefulness of a D-marker needs to be evaluated by a series of parameters, including high sensitivity, high specificity and high positive/negative predictive value (PPV/NPV). As additional statistical parameters used for D-markers, the positive likelihood ratio (LR), and the area under the curve (AUC), derived from receiver operator curve (ROC) analyses, are used to assess the probability that a positive or negative test indicate those with or without the disease (e.g. liver fibrosis).

A B-marker, in contrast, should be able to assess the severity and the extent of disease within the group of individuals, who are classified as having the diagnosis by using the diagnostic marker. This is evaluated typically at a single time point in either baseline assessments of subjects enrolled in a clinical trial or by examining cross-sectional data of individuals with liver disease from different cohorts. In this case, the necessary comparison with the gold standard is focused on disease severity; while the parameters used to assess B-markers are similar to those used for D-markers.

A P-marker is a marker that predicts either the future onset or the progression of the disease. Longitudinal studies (both prospective and retrospective) are required to evaluate this kind of markers, showing an association of the marker at baseline with the risk of progression or of developing the disorder. The purpose of a P-marker is to predict future episodes and not to classify individuals by a given criteria. Relative risk (RR) or odds ratio (OR), given the presence or absence of the marker, are used to describe dichotomous or categorical outcomes, while the RR or OR per SD increase or decrease in the marker, and/or the AUC estimated from ROC are used for P-markers examined as continuous variables. Thus, for an outcome such as progression of the disease assessed by a liver histopathology score, the methods of analyses are different from those of D- and B-markers.

An ideal E-marker is a serum biomarker of disease that, when measured serially, is associated with an improved or beneficial clinical or histopathological out- come among patients who are given a specific treatment, i.e. a surrogate efficacy marker that is predictive for gold standard outcome. In its most simple form it would provide a dichotomous outcome, discriminating between responders and non-responders, and in other settings it provides information about efficacy of treatment among individuals at high risk of developing a given liver disease. The serial evaluation of an E-marker should be focused on the intervention group in a randomized controlled trial. E-markers are typically continuous, and therefore regression models are used for assessment that correlate changes in biomarker levels (e.g. per unit or standard deviations) to changes in an outcome variable.

\section{Classification of liver fibrosis biomarkers according to BIPED}

Despite the fact that in many clinical studies on biomarkers targeting it has been suggested that the proposed biomarkers can be applied as either B- or Dmarkers, less than a handful of the suggested fibrosis biomarkers have reached relevant clinical application up to this point. In Table 3, liver disease biomarkers analyzed in clinical trials is organized according to the new BIPED classification of biomarkers recently introduced in the field of cartilage diseases [7].

The presented framework of assessment focuses on the BIPED categorization, with less attention drawn to sensitivity and specificity performance of the individual markers in the individual studies. In order to compare the performance of different markers with specificity and sensitivity, comparable study populations or even similar assessment techniques performed in the same study population are needed. This is most optimally compared to a gold standard following subsequent odds-ratio calculations. Unfortunately, most study populations are constructed with diseased individuals compared with selected healthy controls, and do therefore not reflect the clinical situation but a nested tailored situation. Hence, the specificity and sensitivity becomes highly dependent on the study population. Classification by the BIPED system may enable researcher from different research backgrounds to communicate in a robust assessment framework, with special focus on diagnostic, prognostic and possible burden of disease evaluations.

An additional category has recently been added to the BIPED classification, namely markers defining the stage of a disease (S-marker) [7]. It can be argued that 
Table 3

Biomarkers of liver fibrosis classified into the BIPED classification

\begin{tabular}{|c|c|c|c|c|c|}
\hline Class & Biomarker & Parameters & $\begin{array}{l}\text { Chronic liver } \\
\text { disease }\end{array}$ & $\begin{array}{l}\text { BIPED } \\
\text { classification }\end{array}$ & Reference \\
\hline I & Hyaluronan & Hyaluronan & $\mathrm{HCV}$ & I, D & {$[15,80,94,127]$} \\
\hline I & IGF-I & IGF-I & $\mathrm{HCV}$ & I & [75] \\
\hline I & Leptin & Leptin & $\mathrm{HCV}$ & I & [76] \\
\hline I & PIIIP & PIIIP & $\mathrm{HCV}$ & I & {$[15]$} \\
\hline Mixed I & MP3 & PIIINP, MMP1 & $\mathrm{HCV}$ & $\mathrm{D}, \mathrm{I}, \mathrm{E}$ & {$[72,120]$} \\
\hline Mixed I & Zheng et al. index & HA, PIIICP, PIIINP, Laminin, C-IV & Chronic hepatitis & I & [131] \\
\hline Mixed I & $\begin{array}{l}\text { Lebensztjen et al. } \\
\text { index }\end{array}$ & $\begin{array}{l}\text { Laminin-2, C-IV, MMP2, MMP9-TIMP1 } \\
\text { index }\end{array}$ & HBV & I & [69] \\
\hline Mixed I & $\begin{array}{l}\text { Lebensztjen et al. } \\
\text { index }\end{array}$ & Tenascin, hyaluronan, Collagen VI, TIMP-1 & HBV & I & {$[70]$} \\
\hline Mixed I & $\begin{array}{l}\text { Tsochatzis et al. } \\
\text { index }\end{array}$ & Leptin, adiponectin, resistin & $\mathrm{HCV}, \mathrm{HBC}, \mathrm{NASH}$ & I & {$[121]$} \\
\hline Mixed I & Patel et al. index & Hyaluronan, TIMP-1, $\alpha_{2}$-macroglobulin & $\mathrm{HCV}$ & $\mathrm{D}, \mathrm{I}$ & [95] \\
\hline Mixed I & Lieber et al. & $\begin{array}{l}\text { TIMP-1, tenascin, collagen IV, PIIINP, } \\
\text { MMP2, laminin, Hyaluronan }\end{array}$ & NASH & I & [73] \\
\hline II & Forns-index & Age, platelet count, $\gamma \mathrm{GT}$, cholesterol & $\mathrm{HCV} \mathrm{HIV/HCV}$ & $\mathrm{D}, \mathrm{I}$ & {$[11,13,28,72,90]$} \\
\hline II & FibroTest & $\begin{array}{l}\text { Haptoglobin, } \alpha_{2} \text {-macroglobulin, } \\
\text { apolipoprotein A1, } \gamma \mathrm{GT} \text {, bilirubin }\end{array}$ & $\begin{array}{l}\mathrm{HCV} \text { HIV/HCV } \\
\text { NAFLD NAFLD in } \\
\text { diabetes patients }\end{array}$ & $\mathrm{I}, \mathrm{D}, \mathrm{E}$ & $\begin{array}{l}{[11,13,40,44,45,55,72} \\
73,88,90,91,92,99,102 \\
104,105,109]\end{array}$ \\
\hline II & Actitest & FibroTest + ALT & $\mathrm{HCV}$ & $\mathrm{I}, \mathrm{D}, \mathrm{E}$ & {$[44,87,100,101]$} \\
\hline II & $\begin{array}{l}\text { APRI } \\
\text { (Wai-index) }\end{array}$ & AST, platelet count & $\begin{array}{l}\text { HIV/HCV HCV } \\
\text { NAFLD }\end{array}$ & $\mathrm{D}, \mathrm{I}$ & $\begin{array}{l}{[2,11,13,14,17,44,51,72} \\
73,92,97,99,120,121,126]\end{array}$ \\
\hline II & Hepascore & $\begin{array}{l}\text { Bilirubin, } \gamma \mathrm{GT} \text {, hyaluronan, } \\
\alpha_{2} \text {-macroglobulin, age, gender }\end{array}$ & HCV HIV/HCV & $\mathrm{D}, \mathrm{I}, \mathrm{B}$ & {$[1,13,43,71,72]$} \\
\hline II & FIB-4 & Platelet count, AST, ALT, age & $\mathrm{HIV} / \mathrm{HCV}$ & $\mathrm{I}, \mathrm{D}$ & {$[13,119]$} \\
\hline II & SHASTA & Hyaluronan, albumin, AST & $\mathrm{HIV} / \mathrm{HCV}$ & I & [13] \\
\hline II & Fibroindex & FORN+APRI & $\mathrm{HCV}$ & $\mathrm{D}, \mathrm{I}, \mathrm{E}$ & {$[65]$} \\
\hline II & Fibrometer test & $\begin{array}{l}\text { Platelet count, prothrombin index, AST, } \alpha_{2-} \\
\text { macroglobulin, hyaluronan, urea, age }\end{array}$ & $\begin{array}{l}\mathrm{HIV} / \mathrm{HCV} \mathrm{HCV} \\
\text { NAFLD }\end{array}$ & $\mathrm{D}, \mathrm{I}$ & {$[13,14,43,71,72]$} \\
\hline II & NFSA & $\begin{array}{l}\text { Age, hyperglycaemia, body mass index, } \\
\text { platelets, albumin, AST/ALT }\end{array}$ & NAFLD & I & [14] \\
\hline II & $\begin{array}{l}\text { Ultrasound }+ \\
\text { APRI }\end{array}$ & AST, platelet count, Ultrasound & $\mathrm{HCV}$ & $\mathrm{D}, \mathrm{I}$ & {$[92]$} \\
\hline II & $\begin{array}{l}\text { Metwally et al. } \\
\text { index }\end{array}$ & $\begin{array}{l}\text { Platelet count, albumin, AST, history of } \\
\text { blood transfusion, HBV core antibody }\end{array}$ & $\mathrm{HCV}$ & $\mathrm{D}, \mathrm{I}$ & {$[81]$} \\
\hline II & $\begin{array}{l}\text { Mohamadnejad } \\
\text { et al. index }\end{array}$ & $\begin{array}{l}\text { Age, HBV DNA levels, alkaline phos- } \\
\text { phatase, albumin, platelet counts, AST }\end{array}$ & $\mathrm{HCV}$ & $\mathrm{D}, \mathrm{I}$ & [84] \\
\hline II & FibroSpect II & Hyaluronan, TIMP-1, $\alpha_{2}$-macroglobulin & $\mathrm{HCV}$ & $\mathrm{D}, \mathrm{I}$ & {$[96,114,129]$} \\
\hline II & $\begin{array}{l}\text { Stepwise combin- } \\
\text { ation algorithms }\end{array}$ & Combination of APRI and Fibrotest & $\mathrm{HCV}$ & $\mathrm{D}, \mathrm{I}$ & [112] \\
\hline II & $\begin{array}{l}\text { Imbert-Bismut } \\
\text { index }\end{array}$ & $\begin{array}{l}\alpha_{2} \text { macroglobulin, AST, ALT } \gamma \mathrm{GT} \text {, total } \\
\text { bilirubin, albumin, } \alpha_{1} \text { globulin, } \alpha_{2} \text { globulin, } \\
\beta \text { globulin, } \gamma \text { globulin, apolipoprotein } \mathrm{A}_{1}\end{array}$ & $\mathrm{HCV}$ & I & {$[51]$} \\
\hline II & Nunes et al. & $\begin{array}{l}\text { Age, Platelets, INR, CD4, AST/ALT, } \\
\text { Hyaluronan, YKL-40, PIIINP }\end{array}$ & HCV/HIV HCV & $\mathrm{D}, \mathrm{I}$ & {$[90]$} \\
\hline II & Fibroscan +++ & Fibroscan, Fibrotest, APRI & $\mathrm{HCV}$ & $\mathrm{D}, \mathrm{I}$ & {$[18]$} \\
\hline
\end{tabular}

staging markers are in fact B-markers assessing the extent of disease. In arthritis, markers of this class are capable of measuring the severity within a particular joint, and/or severity in terms of number of joints involved. We postulate that, in liver fibrosis, staging markers are a subcategory of the burden of disease-markers, assuming that fibrosis is equally distributed in the entire liver, an assumption that is also made on liver biopsy sampling. However, this is not necessarily the case as was described previously, and a new category therefore had to be established for the staging markers.

Biochemical markers measured in serum/urine are the product of systemic events, in which many local specific events contribute to that pool of biomarker epitope. Biomarkers require validation as the assessment of the assay or measurement performance characteristics including sensitivity, specificity, and reproducibility $[116,123]$. Even though some biochemical markers 
A

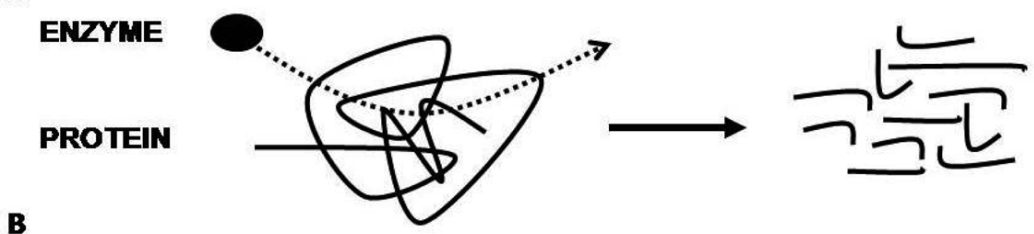

\section{ENZYME \\ PROTEIN

ANTIBODY
SPECIFIC
FOR
NEOEPITOPE

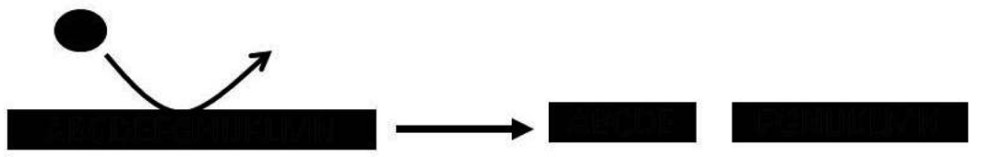

C

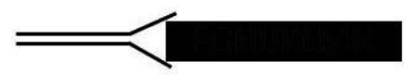

Fig. 4. Neo-epitopes - protease degradation of proteins. A) Fragments are generated of a protein by enzymatic activity. B) The enzymatic cleavage leads to two highly specific fragments. C) After blasting and homology search antibodies are developed against the specific cleavage site. During development the antibodies are screen against different de-selection peptides (e.g. elongated peptides) to make sure the developed antibody do not react with the whole protein, but reacts only against the generated specific cleavage site- the neo-epitope.

have been shown to correlate with the number of affected sites, such as collagen type II degradation markers and number of affected joints in OA [82], tissue specificity and pathological relation must be carefully evaluated, possible by application of the BIPED criteria [7,57]. Particular emphasis should be directed to whether novel markers may be a diagnostic or prognostic marker [57]. Even though the combined approached with proteases degradation fragments may increase the accuracy of the biomarker, the exact tissue distribution and contribustion deserves attention to obtain maximal disease accuracy and assay precision.

\section{The neo-epitope approach}

Different approaches exist to biochemical biomarker development [105,110]. The main approached taken are an unbiased proteomic approach involving a range of powerful techniques [66,130], and a more simple hypothesis driven approach [57]. Each approach provide advantages and drawback, however a deeper discussion is out of the current scope.

Matrix remodeling is an integrated process of tissue development, maintenance and pathogenesis.

Endopeptidases such as MMPs and cysteine proteases play major roles in the degradation of extracellular macromolecules such as the collagen and proteoglycans. The proteolytic action of the MMPs results in generation of specific cleavage fragments, called neo- epitopes (Fig. 4). Even though many components of the ECM as well as enzymes responsible for remodeling may overlap between different tissues, the combination of a specific protease and a specific ECM protein component may provide a unique combination for a specific tissue or a specific disease mechanism.

The neo-epitope approach has been used extensively in bone and cartilage diseases which are diseases with extensive ECM remodeling [109]. In alignment with the BIPED criteria, serological markers of diagnosis, efficacy and prognosis have been identified and exploited during drug development for osteoarthritis and osteoporosis [109]. Imbalance between tissue formation and tissue degradation is involved in both diseases. For example, evidence points to the fact that postmenopausal bone loss is the result of both an increase in bone resorption and an increase in bone formation, where the excessive bone resorption leads to a net bone loss [58]. Furthermore, MMP generated fragments of type II collagen (CTX-II), have been demonstrated and extensibley used in osteoarthritis as both a diagnostic, prognostic and efficacy marker [4,22,104], thereby assisting researchers in understanding key biological questions related to progression of the disease.

These key learnings may be transferred into the area of liver fibrosis. The enzymes presently receiving the most attention in the liver fibrosis field are the MMPs in combination with collagen type I and III, and proteasegenerated fragments of collagen types I and III may be relevant targets for biochemical markers development for measuring high turnover during fibrogenesis. 
At present there are limited ECM neo-epitope studies concerning liver fibrosis. Guañabens $\mathrm{N}$ et al. [40] evaluated the bone turnover markers $\mathrm{N}$-telopeptide of type I collagen (NTX), C-telopeptide of type I collagen (CTX) and N-terminal pro-peptide of collagen type I (PINP) in 34 women with primary biliary cirrhosis, a disease with increased liver fibrosis. The aim was to evaluate the influence of a nonskeletal disease with increased connective tissue synthesis or degradation on the levels of the bone turnover markers. The level of NTX, CTX and PINP were elevated in patients compared to controls and correlated with the histological stage of the disease. Even though the levels correlates with the disease, the bone turnover markers would give a high background in many liver fibrosis diseases due to high bone turnover, which is a typical complication in fibrotic liver diseases [19,21,93].

\section{Conclusion}

We have introduced the BIPED classifiction and classified the existing liver fibrosis biomarkers used in clinical trial according to this system. Although considerable work has been done, none of the biomarkers have yet proved itself suitable for clinical use in the evaluation of patients with chronic liver disease. We recommend that the BIPED criterion is implemented in the development and validation of biomarkers, so that clinicians and researchers are easily guided in the use of existing and future biomarkers. We would also like to draw attention to the neo-epitope approach, which has provided instrumental biochemical marker tools for researchers within the fields of osteoarthritis and osteoporois. As many pathologies involves extensive extracellular matrix remodelling, and fibrotic diseases in particular are related to extensive ECMR with matrix deposition and protease expression/regulations, the lessons learned from pathologies may suggestan optimized strategy for targeting specific tissue components with real pathophysiological significance.

The ultimate goal for the use of biomarkers is to increase the sensitivity and the specificity of the followup of chronic liver patients, minimizing the need for invasive liver biopsy procedures in this clinical setting. Application of biomarkers would provide the clinicians with improved tools to personalize the treatment, to follow the progression of the disease and to monitor the response to treatment.

\section{Declaration}

Sanne Skovgård-Veidal, Anne-Christine Bay-Jensen and Morten Asser Karsdal are employees of Nordic Bioscience. Gervais Tougas is an employee of Novartis. Morten Asser Karsdal owns stocks and shares in Nordic Bioscience.

\section{References}

[1] L.A. Adams, M. Bulsara, E. Rossi, B. DeBoer, D. Speers, J. George, J. Kench, G. Farrell, G.W. McCaughan and G.P. Jeffrey, Hepascore: an accurate validated predictor of liver fibrosis in chronic hepatitis C infection, Clin Chem 51 (2005), 1867-1873.

[2] H. Al-Mohri, C. Cooper, T. Murphy and M.B. Klein, Validation of a simple model for predicting liver fibrosis in HIV/hepatitis C virus-coinfected patients, HIV Med 6 (2005), 375-378.

[3] M.J. Arthur, Fibrogenesis II. Metalloproteinases and their inhibitors in liver fibrosis, Am J Physiol Gastrointest Liver Physiol 279 (2000), G245-G249.

[4] Y.Z. Bagger, L.B. Tanko, P. Alexandersen, M.A. Karsdal, M. Olson, L. Mindeholm, M. Azria and C. Christiansen, Oral salmon calcitonin induced suppression of urinary collagen type II degradation in postmenopausal women: a new potential treatment of osteoarthritis, Bone 37 (2005), 425-430.

[5] A.H. Bartlett, K. Hayashida and P.W. Park, Molecular and cellular mechanisms of syndecans in tissue injury and inflammation, Mol Cells 24 (2007), 153-166.

[6] R. Bataller and D.A. Brenner, Liver fibrosis, J Clin Invest 115 (2005), 209-218.

[7] D.C. Bauer, D.J. Hunter, S.B. Abramson, M. Attur, M. Corr, D. Felson, D. Heinegard, J.M. Jordan, T.B. Kepler, N.E. Lane, T. Saxne, B. Tyree and V.B. Kraus, Classification of osteoarthritis biomarkers: a proposed approach, Osteoarthritis Cartilage 14 (2006), 723-727.

[8] R.C. Benyon and M.J. Arthur, Extracellular matrix degradation and the role of hepatic stellate cells, Semin Liver Dis 21 (2001), 373-384.

[9] T.C. Blochberger, P.K. Cornuet and J.R. Hassell, Isolation and partial characterization of lumican and decorin from adult chicken corneas. A keratan sulfate-containing isoform of decorin is developmentally regulated, J Biol Chem 267 (1992), 20613-20619.

[10] E. Borkham-Kamphorst, C.R. van Roeyen, T. Ostendorf, J. Floege, A.M. Gressner and R. Weiskirchen, Pro-fibrogenic potential of PDGF-D in liver fibrosis, J Hepatol 46 (2007), 1064-1074.

[11] M. Bourliere, G. Penaranda, C. Renou, D. Botta-Fridlund, A. Tran, I. Portal, L. Lecomte, P. Castellani, M.A. RosenthalAllieri, R. Gerolami, D. Ouzan, R. Deydier, C. Degott and P. Halfon, Validation and comparison of indexes for fibrosis and cirrhosis prediction in chronic hepatitis $\mathrm{C}$ patients: proposal for a pragmatic approach classification without liver biopsies, J Viral Hepat 13 (2006), 659-670.

[12] M. Buck and M. Chojkier, A ribosomal S-6 kinase-mediated signal to C/EBP-beta is critical for the development of liver fibrosis, PLoS ONE 2 (2007), e1372. 
[13] P. Cacoub, F. Carrat, P. Bedossa, J. Lambert, G. Penaranda, C. Perronne, S. Pol and P. Halfon, Comparison of non-invasive liver fibrosis biomarkers in HIV/HCV co-infected patients: the fibrovic study-ANRS HC02, J Hepatol 48 (2008), 765773.

[14] P. Cales, F. Laine, J. Boursier, Y. Deugnier, V. Moal, F. Oberti, G. Hunault, M.C. Rousselet, I. Hubert, J. Laafi, P.H. Ducluzeaux and F. Lunel, Comparison of blood tests for liver fibrosis specific or not to NAFLD, J Hepatol, 2008.

[15] V.R. Camacho, T.R. Silveira, J.R. Oliveira, S.G. Barros and C.T. Cerski, Relationship between serum concetrations of type III procollagen, hyluronic acid and histopathological findings in the liver of HCV-positive blood donors, Arq Gastroenterol 44 (2007), 118-122.

[16] R.J. Carvalho-Filho, L.L. Schiavon, J.L. Narciso-Schiavon, J.P. Sampaio, V.P. Lanzoni, M.L. Ferraz and A.E. Silva, Optimized cutoffs improve performance of the aspartate aminotransferase to platelet ratio index for predicting significant liver fibrosis in human immunodeficiency virus/hepatitis C virus co-infection, Liver Int 28 (2008), 486-493.

[17] P. Castagnola, S. Tavella, D.R. Gerecke, B. Dublet, M.K. Gordon, J. Seyer, R. Cancedda, R.M. van der and B.R. Olsen, Tissue-specific expression of type XIV collagen-a member of the FACIT class of collagens, Eur J Cell Biol 59 (1992), 340-347.

[18] L. Castera, J. Vergniol, J. Foucher, B.B. Le, E. Chanteloup, M. Haaser, M. Darriet, P. Couzigou, L. de, V, Prospective comparison of transient elastography, Fibrotest, APRI, and liver biopsy for the assessment of fibrosis in chronic hepatitis C, Gastroenterology 128 (2005), 343-350.

[19] C. Cijevschi, C. Mihai, V.L. Drug, E. Zbranca and P. Gogalniceanu, Osteoporosis in liver cirrhosis-overview, Rev Med Chir Soc Med Nat Iasi 109 (2005), 700-704.

[20] J. Collazos and F. Diaz, Procollagen-III peptide concentrations in serum of patients with chronic active hepatitis compared with mild hepatic disorders, Clin Biochem 27 (1994), 189-191.

[21] J. Collier, Bone disorders in chronic liver disease, Hepatology 46 (2007), 1271-1278.

[22] E.B. Dam, I. Byrjalsen, M.A. Karsdal, P. Qvist and C. Christiansen, Increased urinary excretion of C-telopeptides of type II collagen (CTX-II) predicts cartilage loss over 21 months by MRI, Osteoarthritis Cartilage 17 (2009), 384-389.

[23] V.J. Desmet and T. Roskams, Cirrhosis reversal: a duel between dogma and myth, J Hepatol 40 (2004), 860-867.

[24] J.L. Dienstag, R.D. Goldin, E.J. Heathcote, H.W. Hann, M. Woessner, S.L. Stephenson, S. Gardner, D.F. Gray and E.R. Schiff, Histological outcome during long-term lamivudine therapy, Gastroenterology 124 (2003), 105-117.

[25] J. Dudas, I. Kovalszky, M. Gallai, J.O. Nagy, Z. Schaff, T. Knittel, M. Mehde, K. Neubauer, F. Szalay and G. Ramadori, Expression of decorin, transforming growth factor-beta 1, tissue inhibitor metalloproteinase 1 and 2, and type IV collagenases in chronic hepatitis, Am J Clin Pathol 115 (2001), 725-735.

[26] L.W. Fisher, J.D. Termine and M.F. Young, Deduced protein sequence of bone small proteoglycan I (biglycan), shows homology with proteoglycan II (decorin), and several nonconnective tissue proteins in a variety of species, $\mathrm{J}$ Biol Chem 264 (1989), 4571-4576.

[27] S.J. Forbes, F.P. Russo, V. Rey, P. Burra, M. Rugge, N.A. Wright and M.R. Alisonm, A significant proportion of myofibroblasts are of bone marrow origin in human liver fibrosis, Gastroenterology 126 (2004), 955-963.
[28] X. Forns, S. Ampurdanes, J.M. Llovet, J. Aponte, L. Quinto, E. Martinez-Bauer, M. Bruguera, J.M. Sanchez-Tapias and J. Rodes, Identification of chronic hepatitis $\mathrm{C}$ patients without hepatic fibrosis by a simple predictive model, Hepatology 36 (2002), 986-992.

[29] S.L. Friedman, Liver fibrosis - from bench to bedside, $J$ Hepatol 38(Suppl 1) (2003), S38-S53.

[30] S.L. Friedman, Hepatic fibrosis - overview, Toxicology 254 (2008), 120-129.

[31] S.L. Friedman, F.J. Roll, J. Boyles and D.M. Bissell, Hepatic lipocytes: the principal collagen-producing cells of normal rat liver, Proc Natl Acad Sci U S A 82 (1985), 8681-8685.

[32] N. Gagliano, B. Arosio, F. Grizzi, S. Masson, J. Tagliabue, N. Dioguardi, C. Vergani and G. Annoni, Reduced collagenolytic activity of matrix metalloproteinases and development of liver fibrosis in the aging rat, Mech Ageing Dev 123 (2002), 413-425.

[33] M. Gallai, I. Kovalszky, T. Knittel, K. Neubauer, T. Armbrust and G. Ramadori, Expression of extracellular matrix proteoglycans perlecan and decorin in carbon-tetrachloride-injured rat liver and in isolated liver cells, Am J Pathol 148 (1996), 1463-1471.

[34] K. Gelse, E. Poschl and T. Aigner, Collagens - structure, function, and biosynthesis, Adv Drug Deliv Rev 55 (2003), 1531-1546

[35] A.M. Gressner, N. Krull and M.G. Bachem, Regulation of proteoglycan expression in fibrotic liver and cultured fatstoring cells, Pathol Res Pract 190 (1994), 864-882.

[36] A.M. Gressner and R. Weiskirchen, Modern pathogenetic concepts of liver fibrosis suggest stellate cells and TGF-beta as major players and therapeutic targets, J Cell Mol Med $\mathbf{1 0}$ (2006), 76-99.

[37] O.A. Gressner, R. Weiskirchen and A.M. Gressner, Biomarkers of hepatic fibrosis, fibrogenesis and genetic predisposition pending between fiction and reality, $\mathrm{J}$ Cell $\mathrm{Mol}$ Med 11 (2007), 1031-1051.

[38] O.A. Gressner, R. Weiskirchen and A.M. Gressner, Biomarkers of liver fibrosis: clinical translation of molecular pathogenesis or based on liver-dependent malfunction tests, Clin Chim Acta 381 (2007), 107-113.

[39] M. Grigorescu, M. Rusu, D. Neculoiu, C. Radu, A. Serban, M. Catanas and M.D. Grigorescu, The FibroTest value in discriminating between insignificant and significant fibrosis in chronic hepatitis $C$ patients. The Romanian experience, $J$. Gastrointestin Liver Dis 16 (2007), 31-37.

[40] N. Guanabens, A. Pares, L. Alvarez, M.J. Martinez de Osaba, A. Monegal, P. Peris, A.M. Ballesta and J. Rodes, Collagenrelated markers of bone turnover reflect the severity of liver fibrosis in patients with primary biliary cirrhosis, $J$ Bone Miner Res 13 (1998), 731-738.

[41] J. Guechot, A.Laudat, A. Loria, L. Serfaty, R. Poupon and J. Giboudeau, Diagnostic accuracy of hyaluronan and type III procollagen amino-terminal peptide serum assays as markers of liver fibrosis in chronic viral hepatitis $\mathrm{C}$ evaluated by ROC curve analysis, Clin Chem 42 (1996) 558-563.

[42] C. Guyot, S. Lepreux, C. Combe, E. Doudnikoff, P. BioulacSage, C. Balabaud and A. Desmouliere, Hepatic fibrosis and cirrhosis: the (myo)fibroblastic cell subpopulations involved, Int J Biochem Cell Biol 38 (2006), 135-151.

[43] P. Halfon, Y. Bacq, M.A. De, G. Penaranda, M. Bourliere, D. Ouzan, A. Tran, D. Botta, C. Renou, M.C. Brechot, C. Degott and V. Paradis, Comparison of test performance profile for blood tests of liver fibrosis in chronic hepatitis C, J Hepatol 46 (2007), 395-402. 
[44] P. Halfon, M. Bourliere, R. Deydier, D. Botta-Fridlund, C. Renou, A. Tran, I. Portal, I. Allemand, J.J. Bertrand, A. Rosenthal-Allieri, M. Rotily, C. Sattonet, T. Benderitter, M.C. Saint Paul, H.P. Bonnot, G. Penaranda, C. Degott, M.F. Masseyeff and D. Ouzan, Independent prospective multicenter validation of biochemical markers (fibrotest-actitest), for the prediction of liver fibrosis and activity in patients with chronic hepatitis C: the fibropaca study, Am J Gastroenterol 101 (2006), 547-555.

[45] P. Hammel, A. Couvelard, D. O'Toole, A. Ratouis, A. Sauvanet, J.F. Flejou, C. Degott, J. Belghiti, P. Bernades, D. Valla, P. Ruszniewski and P. Levy, Regression of liver fibrosis after biliary drainage in patients with chronic pancreatitis and stenosis of the common bile duct, $N$ Engl J Med 344 (2001), 418-423.

[46] D. Heinegard and A. Oldberg, Structure and biology of cartilage and bone matrix noncollagenous macromolecules, FASEB J 3 (1989), 2042-2051.

[47] S. Hemmann, J. Graf, M. Roderfeld and E. Roeb, Expression of MMPs and TIMPs in liver fibrosis - a systematic review with special emphasis on anti-fibrotic strategies, J. Hepatol. 46 (2007), 955-975.

[48] K. Henriksen, L.B. Tanko, P. Qvist, P.D. Delmas, C. Christiansen and M.A. Karsdal, Assessment of osteoclast number and function: application in the development of new and improved treatment modalities for bone diseases, Osteoporos Int 18 (2007), 681-685.

[49] B. Hogemann, G. Edel, K. Schwarz, R. Krech and H. Kresse, Expression of biglycan, decorin and proteoglycan-100/CSF1 in normal and fibrotic human liver, Pathol Res Pract 193 (1997), 747-751.

[50] L. Hongbo, L. Xiaohui, K. Hong, W. Wei and Z. Yong, Assessing routine and serum markers of liver fibrosis in $\mathrm{CHB}$ patients using parallel and serial interpretation, Clin Biochem 40 (2007), 562-566.

[51] F. Imbert-Bismut, V. Ratziu, L. Pieroni, F. Charlotte, Y. Benhamou and T. Poynard, Biochemical markers of liver fibrosis in patients with hepatitis $\mathrm{C}$ virus infection: a prospective study, Lancet 357 (2001), 1069-1075.

[52] K. Ishak, A. Baptista, L. Bianchi, F. Callea, G.J. De, F. Gudat, H. Denk, V. Desmet, G. Korb and R.N. MacSween, Histological grading and staging of chronic hepatitis, J Hepatol 22 (1995), 696-699.

[53] R. Issa, X. Zhou, C.M. Constandinou, J. Fallowfield, H Millward-Sadler, M.D. Gaca, E. Sands, I. Suliman, N. Trim, A. Knorr, M.J. Arthur, R.C. Benyon and J.P. Iredale, Spontaneous recovery from micronodular cirrhosis: evidence for incomplete resolution associated with matrix cross-linking, Gastroenterology 126 (2004), 1795-1808.

[54] S. Jacqueminet, P. Lebray, R. Morra, M. Munteanu, L. Devers, D. Messous, M. Bernard, A. Hartemann-Heurtier, F. Imbert-Bismut, V. Ratziu, A. Grimaldi and T. Poynard, Screening for liver fibrosis by using a noninvasive biomarker in patients with diabetes, Clin Gastroenterol Hepatol 6 (2008), 828-831.

[55] W.R. Jarnagin, D.C. Rockey, V.E. Koteliansky, S.S. Wang and D.M. Bissell, Expression of variant fibronectins in wound healing: cellular source and biological activity of the EIIIA segment in rat hepatic fibrogenesis, J Cell Biol 127 (1994), 2037-2048.

[56] R. Kalluri and E.G. Neilson, Epithelial-mesenchymal transition and its implications for fibrosis, J Clin Invest 112 (2003), 1776-1784.
[57] M.A. Karsdal, K. Henriksen, D.J. Leeming, P. Mitchell, K. Duffin, N. Barascuk, L. Klickstein, P. Aggarwal, O. Nemirovskiy, I. Byrjalsen, P. Qvist, A.C. Bay-Jensen, E.B. Dam, S.H. Madsen and C. Christiansen, Biochemical markers and the FDA Critical Path: how biomarkers may contribute to the understanding of pathophysiology and provide unique and necessary tools for drug development, Biomarkers 14 (2009), 181-202.

[58] M.A. Karsdal, T.J. Martin, J. Bollerslev, C. Christiansen and K. Henriksen, Are nonresorbing osteoclasts sources of bone anabolic activity? J Bone Miner Res 22 (2007), 487-494.

[59] M.A. Karsdal, P. Qvist, C. Christiansen and L.B. Tanko, Optimising antiresorptive therapies in postmenopausal women: why do we need to give due consideration to the degree of suppression? Drugs 66 (2006), 1909-1918.

[60] C. Kiani, L. Chen, Y.J. Wu, A.J. Yee and B.B. Yang, Structure and function of aggrecan, Cell Res 12 (2002), 19-32.

[61] N. Kinnman, C. Francoz, V. Barbu, D. Wendum, C. Rey, R. Hultcrantz, R. Poupon and C. Housset, The myofibroblastic conversion of peribiliary fibrogenic cells distinct from hepatic stellate cells is stimulated by platelet-derived growth factor during liver fibrogenesis, Lab Invest 83 (2003), 163-173.

[62] R. Kittelberger, P.F. Davis, D.W. Flynn and N.S. Greenhill, Distribution of type VIII collagen in tissues: an immunohistochemical study, Connect Tissue Res 24 (1990), 303-318.

[63] D.E. Kleiner, E.M. Brunt, N.M. Van, C. Behling, M.J. Contos, O.W. Cummings, L.D. Ferrell, Y.C. Liu, M.S. Torbenson, A. Unalp-Arida, M. Yeh, A.J. McCullough and A.J. Sanyal, Design and validation of a histological scoring system for nonalcoholic fatty liver disease, Hepatology $\mathbf{4 1}$ (2005), 1313-1321.

[64] R.G. Knodell, K.G. Ishak, W.C. Black, T.S. Chen, R. Craig, N. Kaplowitz, T.W. Kiernan and J. Wollman, Formulation and application of a numerical scoring system for assessing histological activity in asymptomatic chronic active hepatitis, Hepatology 1 (1981), 431-435.

[65] M. Koda, Y. Matunaga, M. Kawakami, Y. Kishimoto, T. Suou and Y. Murawaki, FibroIndex, a practical index for predicting significant fibrosis in patients with chronic hepatitis C, Hepatology 45 (2007) 297-306.

[66] E.C. Kohn, N. Azad, C. Annunziata, A.S. Dhamoon and G. Whiteley, Proteomics as a tool for biomarker discovery, Dis. Markers 23 (2007), 411-417.

[67] N.B. Krull and A.M. Gressner, Differential expression of keratan sulphate proteoglycans fibromodulin, lumican and aggrecan in normal and fibrotic rat liver, FEBS Lett 312 (1992), 47-52.

[68] G.J. Laurent, Dynamic state of collagen: pathways of collagen degradation in vivo and their possible role in regulation of collagen mass, Am J Physiol 252 (1987), C1-C9.

[69] D.M. Lebensztejn, M.E. Sobaniec-Lotowska, M. Bauer, M. Kaczmarski, M. Voelker and D. Schuppan, Serum fibrosis markers as predictors of an antifibrotic effect of interferon alfa in children with chronic hepatitis B, Eur J Gastroenterol Hepatol 17 (2005), 843-848.

[70] D.M. Lebensztejn, M.E. Sobaniec-Lotowska, M. Kaczmarski, M. Voelker and D. Schuppan, Matrix-derived serum markers in monitoring liver fibrosis in children with chronic hepatitis B treated with interferon alpha, World J Gastroenterol 12 (2006), 3338-3343.

[71] V. Leroy, P. Halfon, Y. Bacq, J. Boursier, M.C. Rousselet, M. Bourliere, M.A. De, N. Sturm, G. Hunault, G. Penaranda, M.C. Brechot, C. Trocme and P. Cales, Diagnostic accuracy, reproducibility and robustness of fibrosis blood tests 
in chronic hepatitis $\mathrm{C}$ : a meta-analysis with individual data, Clin Biochem 41 (2008), 1368-1376.

[72] V. Leroy, M.N. Hilleret, N. Sturm, C. Trocme, J.C. Renversez, P. Faure, F. Morel and J.P. Zarski, Prospective comparison of six non-invasive scores for the diagnosis of liver fibrosis in chronic hepatitis C, J Hepatol 46 (2007), 775-782.

[73] C.S. Lieber, D.G. Weiss and F. Paronetto, Value of fibrosis markers for staging liver fibrosis in patients with precirrhotic alcoholic liver disease, Alcohol Clin Exp Res 32 (2008), 1031-1039.

[74] W.R. Lin, M. Brittan and M.R. Alison, The Role of Bone Marrow-Derived Cells in Fibrosis, Cells Tissues Organs, 2008.

[75] V. Lorenzo-Zuniga, R. Bartoli, H. Masnou, S. Montoliu, R.M. Morillas and R. Planas, Serum concentrations of insulin-like growth factor-I (igf-I), as a marker of liver fibrosis in patients with chronic hepatitis C, Dig Dis Sci 52 (2007), 3245-3250.

[76] S. Manolakopoulos, S. Bethanis, C. Liapi, F. Stripeli, P. Sklavos, A. Margeli, A. Christidou, A. Katsanika, E. Vogiatzakis, D. Tzourmakliotis and S. Theocharis, An assessment of serum leptin levels in patients with chronic viral hepatitis: a prospective study, BMC Gastroenterol 7 (2007), 17.

[77] P. Marcellin, T. Asselah and N. Boyer, Fibrosis and disease progression in hepatitis C, Hepatology 36 (2002), S47-S56.

[78] A. Martinez-Hernandez and P.S. Amenta, The hepatic extracellular matrix. I. Components and distribution in normal liver, Virchows Arch A Pathol Anat Histopathol 423 (1993), $1-11$.

[79] P.K. Mays, R.J. McAnulty, J.S. Campa and G.J. Laurent, Age-related changes in collagen synthesis and degradation in rat tissues. Importance of degradation of newly synthesized collagen in regulating collagen production, Biochem $J 276(\mathrm{Pt}$ 2) (1991), 307-313

[80] J.G. McHutchison, L.M. Blatt, M. de Medina, J.R. Craig, A. Conrad, E.R. Schiff and M.J. Tong, Measurement of serum hyaluronic acid in patients with chronic hepatitis $\mathrm{C}$ and its relationship to liver histology. Consensus Interferon Study Group, J Gastroenterol Hepatol 15 (2000), 945-951.

[81] M.A. Metwally, C.O. Zein and N.N. Zein, Predictors and noninvasive identification of severe liver fibrosis in patients with chronic hepatitis C, Dig Dis Sci 52 (2007), 582-588.

[82] I. Meulenbelt, M. Kloppenburg, H.M. Kroon, J.J. HouwingDuistermaat, P. Garnero, M.P. Hellio Le Graverand, J. Degroot and P.E. Slagboom, Urinary CTX-II levels are associated with radiographic subtypes of osteoarthritis in hip, knee, hand, and facet joints in subject with familial osteoarthritis at multiple sites: the GARP study, Ann Rheum Dis 65 (2006), 360-365.

[83] D.H. Meyer, N. Krull, K.L. Dreher and A.M. Gressner, Biglycan and decorin gene expression in normal and fibrotic rat liver: cellular localization and regulatory factors, Hepatology 16 (1992), 204-216.

[84] M. Mohamadnejad, G. Montazeri, A. Fazlollahi, F. Zamani, J. Nasiri, H. Nobakht, M.H. Forouzanfar, S. Abedian, S.M. Tavangar, A. Mohamadkhani, F. Ghoujeghi, A. Estakhri, N. Nouri, Z. Farzadi, A. Najjari and R. Malekzadeh, Noninvasive markers of liver fibrosis and inflammation in chronic hepatitis B-virus related liver disease, Am J Gastroenterol 101 (2006), 2537-2545.

[85] R.K. Moreira, Hepatic stellate cells and liver fibrosis, Arch. Pathol, Lab Med 131 (2007), 1728-1734.
[86] J.C. Myers, D. Li, A. Bageris, V. Abraham, A.S. Dion and P.S. Amenta, Biochemical and immunohistochemical characterization of human type XIX defines a novel class of basement membrane zone collagens, Am J Pathol 151 (1997), 1729-1740.

[87] R.P. Myers, M.H. Tainturier, V. Ratziu, A. Piton, V. Thibault, F. Imbert-Bismut, D. Messous, F. Charlotte, M. Di, V, Y. Benhamou and T. Poynard, Prediction of liver histological lesions with biochemical markers in patients with chronic hepatitis B, J Hepatol 39 (2003), 222-230.

[88] S. Naveau, B. Raynard, V. Ratziu, A. Abella, F. ImbertBismut, D. Messous, F. Beuzen, F. Capron, D. Thabut, M. Munteanu, J.C. Chaput and T. Poynard, Biomarkers for the prediction of liver fibrosis in patients with chronic alcoholic liver disease, Clin Gastroenterol Hepatol 3 (2005), 167-174.

[89] Y. Ngo, M. Munteanu, D. Messous, F. Charlotte, F. ImbertBismut, D. Thabut, P. Lebray, V. Thibault, Y. Benhamou, J. Moussalli, V. Ratziu and T. Poynard£< A prospective analysis of the prognostic value of biomarkers (FibroTest) in patients with chronic hepatitis C, Clin Chem 52 (2006), 1887-1896.

[90] D. Nunes, C. Fleming, G. Offner, M. O'Brien, S. Tumilty, O. Fix, T. Heeren, M. Koziel, C. Graham, D.E. Craven, S. Stuver and C.R. Horsburgh, Jr., HIV infection does not affect the performance of noninvasive markers of fibrosis for the diagnosis of hepatitis $\mathrm{C}$ virus-related liver disease, J Acquir Immune Defic Syndr 40 (2005), 538-544.

[91] B.R. Olsen, Life without perlecan has its problems, J Cell Biol 147 (1999), 909-912.

[92] S. Paggi, A. Colli, M. Fraquelli, M. Vigano, P.P. Del, C. Facciotto, M. Colombo, G. Ronchi and D. Conte, A non-invasive algorithm accurately predicts advanced fibrosis in hepatitis $\mathrm{C}$ : a comparison using histology with internal-external validation, J Hepatol 49 (2008), 564-571.

[93] A. Pares and N. Guanabens, Osteoporosis in primary biliary cirrhosis: pathogenesis and treatment, Clin Liver Dis 12 (2008), 407-424.

[94] E.R. Parise, A.C. Oliveira, C. Figueiredo-Mendes, V. Lanzoni, J. Martins, H. Nader and M.L. Ferraz, Noninvasive serum markers in the diagnosis of structural liver damage in chronic hepatitis C virus infection, Liver Int 26 (2006), 1095-1099.

[95] K. Patel, S.C. Gordon, I. Jacobson, C. Hezode, E. Oh, K.M. Smith, J.M. Pawlotsky and J.G. McHutchison, Evaluation of a panel of non-invasive serum markers to differentiate mild from moderate-to-advanced liver fibrosis in chronic hepatitis C patients, J Hepatol 41 (2004), 935-942.

[96] K. Patel, D.R. Nelson, D.C. Rockey, N.H. Afdhal, K.M. Smith, E. Oh, K. Hettinger, M. Vallee, A. Dev, M. SmithRiggs and J.G. McHutchison, Correlation of FIBROSpect II with histologic and morphometric evaluation of liver fibrosis in chronic hepatitis C, Clin Gastroenterol Hepatol 6 (2008), 242-247.

[97] T. Poynard, F. Imbert-Bismut, V. Ratziu, S. Chevret, C. Jardel, J. Moussalli, D. Messous and F. Degos, Biochemical markers of liver fibrosis in patients infected by hepatitis $\mathrm{C}$ virus: longitudinal validation in a randomized trial, $J$ Viral Hepat 9 (2002), 128-133.

[98] T. Poynard, J. McHutchison, M. Manns, C. Trepo, K. Lindsay, Z. Goodman, M.H. Ling and J. Albrecht, Impact of pegylated interferon alfa- $2 \mathrm{~b}$ and ribavirin on liver fibrosis in $\mathrm{pa}-$ tients with chronic hepatitis C, Gastroenterology 122 (2002), 1303-1313.

[99] T. Poynard, R. Morra, P. Halfon, L. Castera, V. Ratziu, F. Imbert-Bismut, S. Naveau, D. Thabut, D. Lebrec, F. Zoulim, 
M. Bourliere, P. Cacoub, D. Messous, M. Munteanu and L. de, V, Meta-analyses of FibroTest diagnostic value in chronic liver disease, BMC Gastroenterol 7 (2007), 40.

[100] T. Poynard, M. Munteanu, F. Imbert-Bismut, F. Charlotte, D. Thabut, C.S. Le, D. Messous, V. Thibault, Y. Benhamou, J. Moussalli and V. Ratziud, Prospective analysis of discordant results between biochemical markers and biopsy in patients with chronic hepatitis C, Clin Chem 50 (2004), 1344-1355.

[101] T. Poynard, F. Zoulim, V. Ratziu, F. Degos, F. Imbert-Bismut, P. Deny, P. Landais, H.A. El, A. Slama, P. Blin, V. Thibault, P. Parvaz, M. Munteanu and C.Trepo, Longitudinal assessment of histology surrogate markers (FibroTest-ActiTest), during lamivudine therapy in patients with chronic hepatitis B infection, Am J Gastroenterol 100 (2005), 1970-1980.

[102] T.E. Quan, S. Cowper, S.P. Wu, L.K. Bockenstedt ann R. Bucala, Circulating fibrocytes: collagen-secreting cells of the peripheral blood, Int J Biochem Cell Biol 36 (2004), 598-606.

[103] V. Ratziu, J. Massard, F. Charlotte, D. Messous, F. ImbertBismut, L. Bonyhay, M. Tahiri, M. Munteanu, D. Thabut, J.F. Cadranel, B.B. Le, L. de, V and T. Poynard, Diagnostic value of biochemical markers (FibroTest-FibroSURE) for the prediction of liver fibrosis in patients with non-alcoholic fatty liver disease, BMC Gastroenterol 6 (2006), 6.

[104] M. Reijman, J.M. Hazes, S.M. Bierma-Zeinstra, B.W. Koes, S. Christgau, C. Christiansen, A.G. Uitterlinden and H.A. Pols, A new marker for osteoarthritis: cross-sectional and longitudinal approach, Arthritis Rheum 50 (2004), 24712478.

[105] K.D. Rodland, Mass spectrometry and biomarker development, Dis Markers 20 (2004), 129-130.

[106] M. Rojkind, M.A. Giambrone and L. Biempica, Collagen types in normal and cirrhotic liver, Gastroenterology 76 (1979), 710-719.

[107] T. Roskams, J. Rosenbaum, V.R. De, G. David and V. Desmet, Heparan sulfate proteoglycan expression in chronic cholestatic human liver diseases, Hepatology 24 (1996), 524-532.

[108] B. Saile and G. Ramadori, Inflammation, damage repair and liver fibrosis-role of cytokines and different cell types, $Z$ Gastroenterol 45 (2007), 77-86.

[109] S. Schaller, K. Henriksen, P. Hoegh-Andersen, B.C. Sondergaard, E.U. Sumer, L.B. Tanko, P. Qvist and M.A. Karsdal, In vitro, ex vivo, and in vivo methodological approaches for studying therapeutic targets of osteoporosis and degenerative joint diseases: how biomarkers can assist? Assay Drug Dev Technol 3 (2005), 553-580.

[110] M. Schrader and H. Selle, The process chain for peptidomic biomarker discovery, Dis Markers 22 (2006), 27-37.

[111] D. Schuppan, M. Ruehl, R. Somasundaram and E.G. Hahn, Matrix as a modulator of hepatic fibrogenesis, Semin Liver Dis 21 (2001), 351-372.

[112] G. Sebastiani, A. Vario, M. Guido, F. Noventa, M. Plebani, R. Pistis, A. Ferrari and A. Alberti, Stepwise combination algorithms of non-invasive markers to diagnose significant fibrosis in chronic hepatitis C, J Hepatol 44 (2006), 686-693.

[113] N. Snyder, L. Gajula, S.Y. Xiao, J. Grady, B. Luxon, D.T. Lau, R. Soloway and J. Petersen, APRI: an easy and validated predictor of hepatic fibrosis in chronic hepatitis C, J Clin Gastroenterol 40 (2006), 535-542.

[114] N. Snyder, A. Nguyen, L. Gajula, R. Soloway, S.Y. Xiao,
D.T. Lau and J. Petersen, The APRI may be enhanced by the use of the FIBROSpect II in the estimation of fibrosis in chronic hepatitis C, Clin Chim Acta 381 (2007), 119-123.

[115] L. Svensson, A. Oldberg and D. Heinegard, Collagen binding proteins, Osteoarthritis and Cartilage 9 (2001), S23-S28.

[116] B.N. Swanson, Delivery of high-quality biomarker assays, Dis Markers 18 (2002), 47-56.

[117] J.A. Talwalkar, Current and emerging surrogate markers of hepatic fibrosis in primary biliary cirrhosis, Liver Int $\mathbf{2 8}$ (2008), 761-763.

[118] Y. Tomono, I. Naito, K. Ando, T. Yonezawa, Y. Sado, S. Hirakawa, J. Arata, T. Okigaki and Y. Ninomiya, Epitopedefined monoclonal antibodies against multiplexin collagens demonstrate that type XV and XVIII collagens are expressed in specialized basement membranes, Cell Struct Funct 27 (2002), 9-20.

[119] T. Trang, J.R. Petersen and N. Snyder, Non-invasive markers of hepatic fibrosis in patients co-infected with HCV and HIV: comparison of the APRI and FIB-4 index, Clin Chim Acta 397 (2008), 51-54.

[120] C. Trocme, V. Leroy, N. Sturm, M.N. Hilleret, S. Bottari, F. Morel and J.P. Zarski, Longitudinal evaluation of a fibrosis index combining MMP-1 and PIIINP compared with MMP-9, TIMP-1 and hyaluronic acid in patients with chronic hepatitis $\mathrm{C}$ treated by interferon-alpha and ribavirin, $J$ Viral Hepat 13 (2006), 643-651.

[121] E. Tsochatzis, G.V. Papatheodoridis, E. Hadziyannis, A. Georgiou, G. Kafiri, D.G. Tiniakos, E.K. Manesis and A.J. Archimandritis, Serum adipokine levels in chronic liver diseases: association of resistin levels with fibrosis severity, Scand J Gastroenterol 43 (2008), 1128-1136.

[122] M.H. von der, M. Aumailley, G. Wick, R. Fleischmajer and R. Timpl, Immunochemistry, genuine size and tissue localization of collagen VI, Eur J Biochem 142 (1984), 493-502.

[123] J.A. Wagner, Overview of biomarkers and surrogate endpoints in drug development, Dis Markers 18 (2002), 41-46.

[124] K. Wallace, A.D. Burt and M.C. Wright, Liver fibrosis, Biochem J 411 (2008), 1-18.

[125] O.H. Weiner, M. Zoremba and A.M. Gressner, Gene expression of syndecans and betaglycan in isolated rat liver cells, Cell Tissue Res 285 (1996), 11-16.

[126] R.G. Wells, Cellular sources of extracellular matrix in hepatic fibrosis, Clin Liver Dis 12 (2008), 759-68, viii.

[127] V.S. Wong, V. Hughes, A. Trull, D.G. Wight, J.Petrik and G.J. Alexander, Serum hyaluronic acid is a useful marker of liver fibrosis in chronic hepatitis $\mathrm{C}$ virus infection, $J$ Viral Hepat 5 (1998), 187-192.

[128] World Health Organization, Reducing Risks, Promoting Healthy Life. 1-230. 2002. Peducing Risks, Promoting Healthy Life, Geneva, WHO. Ref Type: Generic.

[129] A. Zaman, H.R. Rosen, K. Ingram, C.L. Corless, E. Oh and K. Smith, Assessment of FIBROSpect II to detect hepatic fibrosis in chronic hepatitis C patients, Am J Med 120 (2007), $280-14$.

[130] R.C. Zangar, S.M. Varnum, C.Y. Covington and R.D. Smith, A rational approach for discovering and validating cancer markers in very small samples using mass spectrometry and ELISA microarrays, Dis Markers 20 (2004), 135-148.

[131] M. Zheng, W.M. Cai, H.L. Weng and R.H. Liu, ROC curves in evaluation of serum fibrosis indices for hepatic fibrosis, World J Gastroenterol 8 (2002), 1073-1076. 


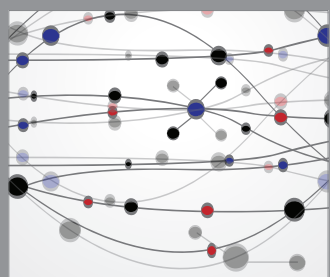

The Scientific World Journal
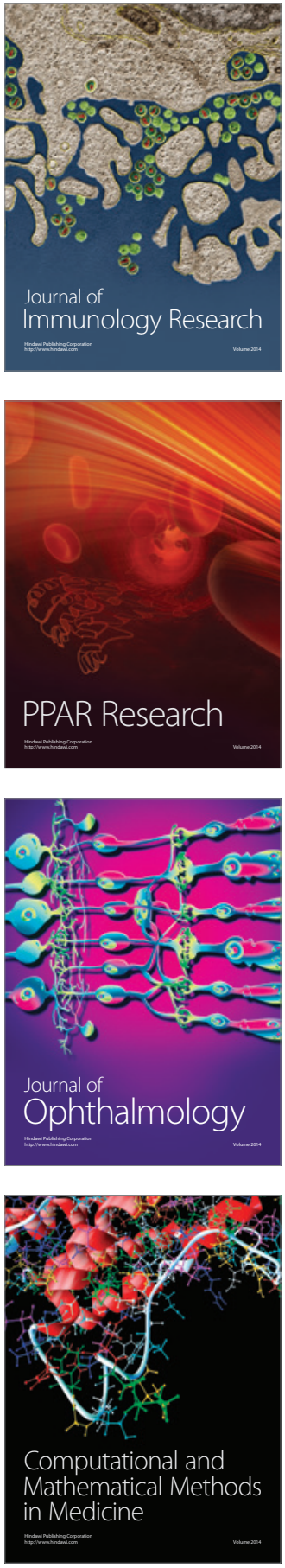

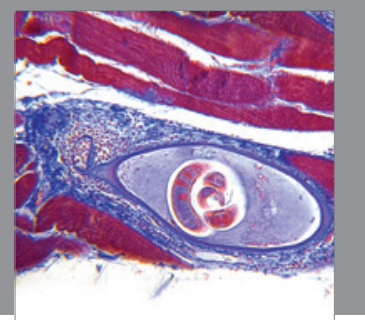

Gastroenterology

Research and Practice
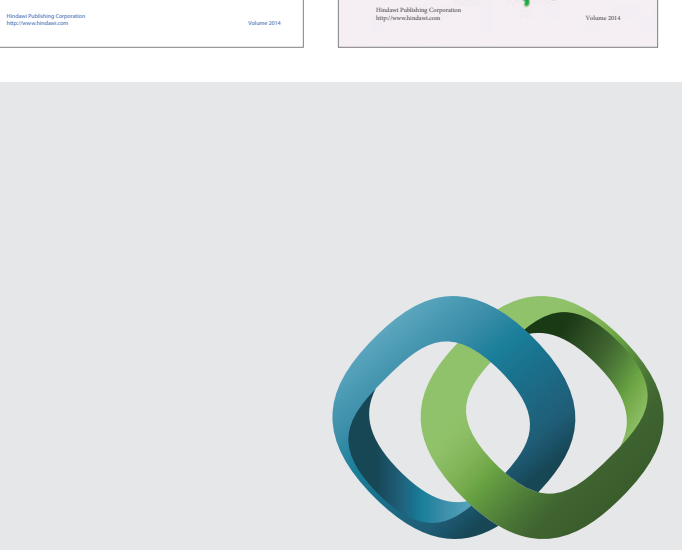

\section{Hindawi}

Submit your manuscripts at

http://www.hindawi.com
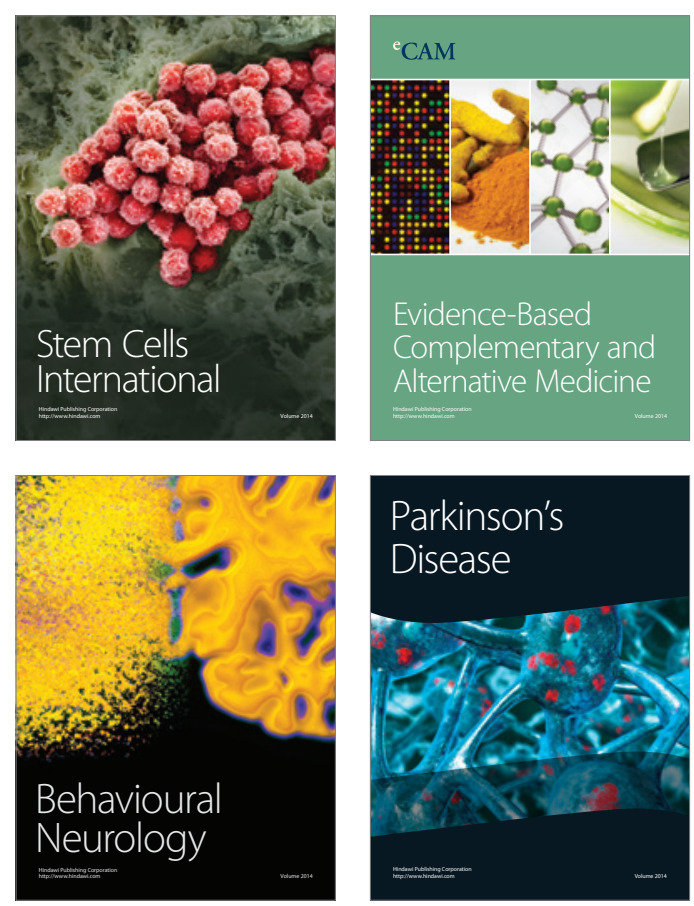

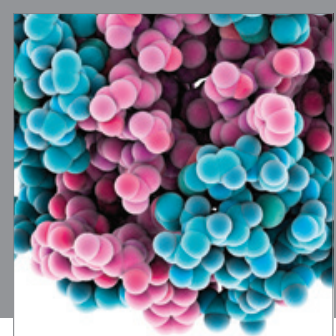

Journal of
Diabetes Research

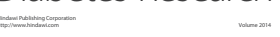

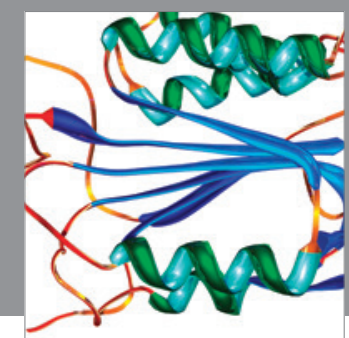

Disease Markers
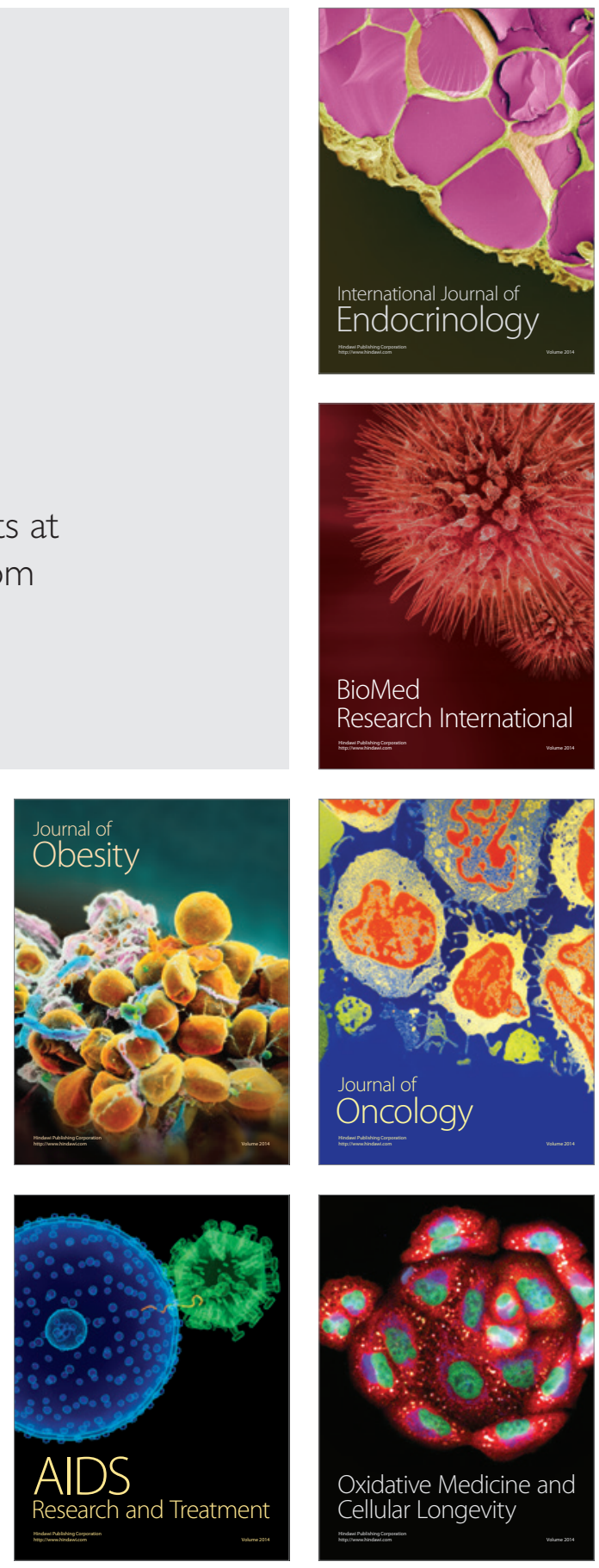